\title{
Evaluation of "Jumat Pintar" Program in Reducing the Incidence of Anemia in Young Women in Sukoharjo, Indonesia
}

\author{
Ayudhia Pratiwi'1), Nunuk Suryani²), Dono Indarto3) \\ 1)Masters Program in Public Health, Sebelas Maret University \\ 2)Faculty of Teaching and Educational Sciences, Sebelas Maret University \\ 3)Department of Physiology, Faculty of Medicine, Sebelas Maret University
}

\begin{abstract}
Background: Anemia is iron deficiency in the body which gives a negative impact. Anemia in the short term can lead to vulnerable young women experience a decline in achievement of learning at school. While long-term, sustained anemia from adolescence until the pregnant can lead to complications of bleeding to death and in Sukoharjo, Jumat Pintar implementation prevents the incidence anemia especially in young women. The activity encouraged from this policy is the giving of Fe tablet. The evaluation was conducted to assess the performance of the implementation of the policy of running and achievements obtained in accordance with the original purpose. This study was aimed to evaluate the implementation of Jumat Pintar program in lowering the incidence of anemia of young women.
\end{abstract}

Subjects and Method: This was a qualitative study, was conducted in September-October 2016 in Sukoharjo. A total of 20 samples were selected by using purposive sampling technique. The data was collected using in depth interviews, observation and study of documentation. The data were analyzed using the interactive analysis techniques to compare the data obtained with data triangulation.

Results: The execution of Jumat Pintar at stages of planning activities, the determination of the amount of goals and services granting Fe tablet was in adherence with the standard procedures of implementation. The stage of the expansion of the network of independent outlets and stages of monitoring and oversight have not run optimally. The scope of consumption of Fe tablet is not can be traced and decrease in the numbers of Genesis anemia in teenagers does not represent the entire area. The main constraints implementation comes from the absence of a legal umbrella agreement work, lack of financial support from various parties, the low commitment of the education sector, and low awareness of the goal.

Conclusion: The implementation of Jumat Pintar is running optimally. The formation of independent outlets have yet to be implemented at each high school in Sukoharjo Regency, the absence of funding sources and still low level of involvement of target.

Keywords: anemia, the movement of young women, the evaluation of the implementation of Jumat Pintar program.

\section{Correspondence:}

Ayudhia Pratiwi. School of Public Health, Sebelas Maret University, Surakarta.

\section{BACKGROUND}

Anemia is still in the spotlight of health problems since the incidence rate which remains high from year to year, despite various efforts of countermeasures that has been conducted. One of the group which is vulnerable to suffer from anemia is young women. Based on 2013 National Basic Health Research (Riskesdas), anemia pre- valence in Indonesia is $21.7 \%$, with $26.4 \%$ is anemia patients of 5-14 years old and $18.4 \%$ is patients of 15 -24 years old. (Kementerian Kesehatan RI, 2015a). Anemia prevalence in Central Java in 2013 reaches 57.1\%.

Young women are prospective mothers who will deliver the future generation. Young women need to prepare their health to be able to deliver quality gene- 
ration. Continuously anemia since adolescence will give negative impact to the pregnancy in the future. According to Wiknjosastro (2007) pregnant women with the history of anemia will increase the risk for hemorrhage both during pregnancy and delivery. As it is reported by Kementerian Kesehatan RI (2015a) hemorrhage is the highest reason for maternal death incidence that is $30.3 \%$. Maternal Mortality Rate (MMR) in Sukoharjo Regency in 2015 also increases compared to 2014, that is $\mathbf{1 5 9 . 0 6}$ per 100,000 live births (Dinkes Sukoharjo, 2016).

The habit of consuming inappropriate daily food intake to maintain ideal body weight leads to nutrients deficiency on the teenager (Dewi et al., 2013), especially for the production of hemoglobin ( $\mathrm{Hb})$. Consumption pattern of young women which is not appropriate such as skipping breakfast, unhealthy diet, menu selection which is not diverse (ignoring source of protein, carbohydrate, vitamin, and mineral ), 1 meal a day, and consuming instant noodle excessively (Dinas Kesehatan Sukoharjo, 2014).

Physiologically, young women regularly lose blood for menstruation every month. It will worsen the anemia incidence if it is not accompanied by sufficient knowledge on the importance of nutrient intake. It is in accordance with a study by Ngatu dan Rohmawwati (2015) that knowledge about anemia on female teenage students holds a positive correlation with the fulfillment of iron need.

Considering the problem Sukoharjo Regency government implements the countermeasure effort for anemia which starts from adolescence. It started back in 2014, when government promoted an activity called "Gerakan Jumat Pintar" (Smart Friday Movement) which was one of main strategy to countermeasure anemia on young women by giving iron tablet supple- ment. The activity of providing iron tablet conducted by Sukoharjo health office aimed at secondary school student group.

Prevention dosage given was 1 tablet/ day for 6 days during menstruation and 1 tablet each week for three month (Kementerian Kesehatan RI, 2014). The target aimed was in accordance with National Medium Term Development Plan 2019 as much as 30\% of young women obtain iron tablet (Kementerian Kesehatan RI, 2015b). The activity that is aimed at young women is conducted trough promotion and campaign at schools and Islamic boarding school independently.

The effectiveness of Gerakan Jumat Pintar needs to be evaluated on the implementation performance whether it has proceeded well or not. The quality of performance is evaluated from the management of iron tablet administration. The purpose of the study was to evaluate the implementation of Gerakan Jumat Pintar policy during preparation stage, implementation process and attainment of accomplishment in overcoming anemia on young women

\begin{tabular}{l}
\hline SUBJECTS AND METHOD \\
\hline Research design used was qualitative \\
phenomenological. Time of implementation \\
was September - October 2016 in Mojo- \\
laban Community Healthcare Center, \\
Nguter Community Healthcare Center, and \\
Kartasura Community Healthcare Center, \\
of Sukoharjo Regency. Research Subject \\
who were willing to informants were 20 \\
people. Sampling technique used was pur- \\
posive sampling with criterion sampling \\
type. Informants from the range of policy \\
makers of Health Office and Community \\
Healthcare Center along with stakeholders \\
from schools side aimed to obtain infor- \\
mation on policy exploration. Informants \\
from young women with anemia were
\end{tabular}


selected to gain information about policy implementation result. Data collection technique used were in depth interview, observation and documentation study. Data were analyzed using interactive analysis technique in which the obtained data from the field were interacted with other data unit.

\section{RESULTS \\ 1. Preparation of Service Provider}

The preparation of service provider needed to be planned before directly implementing the activity of Iron tablet supplementation administration on young women. The first planning was cross sectors agreement. Collaboration stages of cross sectors was initiated from the advocacy of Education Office of Regency Level which subsequently integrated it to Education Office in Subdistrict Level and to schools. However, the weakness in implementing the policy of Gerakan Jumat Pintar was the absence of legal basis (Stipulation Letter or Working Agreement) that is made into the legal foundation of a policy implementation.

"Mr. Ganjar was the one who launched it back in 2014. There is no legal basis, we only think about the marketing" (Health Office)

The result of the study did not find the availability of manual book either that covered the implementation of Gerakan Jumat Pintar activity. Instead, written technical guidelines was greatly needed to understand the purpose and main duty in implementing the policy by field executors.

"There is no manual book or technical guidelines, it seems that none has given from the Regency level” (Nutritionist)

"During socialization back then, the material was given by Regency party, they only explained what is presented in the presentation, there is no manual book distributed." (School Health Unit Officer)
The next component of preparation is from the availability of executors. Nutritionists served as caretaker of the activity it means nutritionists served by doing mentoring and monitoring within the implementation of the activity. The next executor was the officers for School Health Unit (UKS) who served in the administration of iron tablet and monitoring young women's compliance in taking the iron tablet.

"We hand over the implementation in the field to nutritionist in each Community Healthcare Center and at school we hand it over to School Health Unit officers. We only distribute, monitor, and periodically ask for the report from Community Healthcare Center" (Dinkes)

"My duty here are giving socialization to schools and coordinating with School Health Unit officers for the provision of iron tablet, reporting the result of the implementation to Health Office. The there is an ailment from students I will make follow up to be examined by doctor," (Nutritionist).

Despite the result obtained during the interview that all informants of executors actually had understood the main duty that become their responsibility, however the absence of component of stipulation letter, working agreement, technical guidelines and manual book made the implementation of Gerakan Jumat Pintar, which should be understood by the policy makers up to the executor of the policy, was not yet optimal.

\section{Strategy of Information, Education and Communication (IEC)}

The IEC strategy in the policy was conducted through 2 stages of explanation/ sociallization. The first stage was conducted in Regency level, it targetted School Health Unit Officers as the executor in school level, whereas the second stage was socialization from nutritionist of community healthcare center to young women. The socialization 
was conducted in each school, with 100 people as the participants who were selected randomly from school.

"Eee back then there was a letter from health office addressed to schools to send one of the teachers to join the socialization conducted by regency health office...." (School Health Unit Officer)

"It is a collaboration with Community Healthcare Center and is also often attended by Community Health Center and there is explanation for the students usually up to 100 , that is provided for the students. "(Principal)

IEC material provision and formulation was stipulated by Regency Health office which subsequently can be developed by the executor in Community Healthcare Centers. The description of socialization was given by using power point media to attract targets' interests. Therefore the target would pay attention more on the material delivered, the content of IEC component was given thoroughly from the purpose of Gerakan Jumat Pintar, the danger of anemia, treatment for anemia, the benefit of iron tablet supplementation, the effect emerged by consuming iron tablet and food that reacting toward the iron absorption, suggestion for balanced nutrient consumption pattern and advice to form independent outlet.

"In general the material is about prevention and overcoming anemia. The material is from health office and we improvise it"(Nutritionist)

"The material for socialization is a copy from health office and community Healthcare Service is the one who deliver it in socialization" (Nutritionist).

Table 1. The comparison of iron concentration on program iron tablet and independent iron tablet

\begin{tabular}{lc}
\hline \multicolumn{1}{c}{ Name of Iron Tablet } & Iron Concentration \\
\hline Program Iron Tablet & $200 \mathrm{mg}$ Ferrous Sulfate Exicatus \\
Omegavit & $89.5 \mathrm{mg}$ Ferrous Fumarate \\
Fermia & $60 \mathrm{mg}$ Ferrous Fumarate \\
\hline
\end{tabular}

\section{Target and dosage of iron tablet}

Total young women who would get Iron Tablet supplementation was determined by nutritionist in Community Health Center. Data of nutritionist target were obtained from number of female students in each school which were collected by School Health Unit officers.

"Number of targets is suitable with the number of female students in the school. We obtain the data from the application given to the School Health Unit teachers. For 2015 we have 300,300 female students so every female student get one set that contains 30 tablets to be consumed in 90 days" (Nutritionist).

The content used in the iron tablet supplementation was almost similar between program Iron Tablet and Selfsufficient Iron Tablet (Table 1). The administration dosage of program Iron Tablet was one sachet of Iron Tablets contained 30 pills. The pills were taken $1 \mathrm{x}$ per week and every day during menstruation therefore the administration of Iron Tablet on young women was conducted once every 12 weeks. Whereas the administration of Iron Tablets in High School which owned independent outlet was conducted once a week every Friday and it was suggested to be taken at school. Meanwhile the everyday dosage during menstruation was conveyed only through verbal information. 


\section{Procurement and distribution of Iron tablets}

Iron Tablets procurement planning to schools which were still supplied by government as well as to independent outlets was based on the number of real targets. Fund for the procurement of Iron Tablets at schools which still needed Iron Tablets subsidy came from National Revenue and Expenditure and Regency Regional Revenue and Expenditure.

Whereas fund for independent outlets was obtained from female students' contribution and was managed by School Health Unit officers assisted by Youth Red Cross officers.

"Contribution money is managed through Youth Red Cross and later I will buy for them from Pharmacy. Subsequently it will be distributed from me to the students, through Youth Red Cross" (School Health Unit Officers).

The distribution channel of program Iron Tablets came from Pharmacy Warehouse in Regency Level. For Independent Iron Tablets the distribution was conducted independently by School Health Units' officers through pharmacy which was recommended by midwives of Community Healthcare Center.

\section{Observation and Monitoring}

There was no special reporting and recording for observation and monitoring on the implementation of Gerakan Jumat Pintar. It was only evaluated from the result of Iron Tablets administration recording that had been recapitulated in Community Healthcare Centers afterward it was reported to Nutrition Section of Regency Health Office.

"It is me who ask for the report only on the number of targets, how many to be distributed each month, how many take it, that's all (Nutritionist).

The result of the study found that observation and monitoring from the lowest level up to the highest one did not run well. The reporting was conducted only once in every year. Good reporting and observation is conducted regularly and periodically, once in every month or at least in every three months to discover the availability of inventory of Iron tablets and the compliance of young women in consuming Iron Tablets.

\section{Attainment of Accomplishment}

Based on the enlistment survey on anemic young women by Promotion and Nutrition Division of Sukoharjo Health Office in 2015, there are 337 (28.08\%) young women who are detected anemic out of 1,200 young women who conducted $\mathrm{Hb}$ examination (Dinkes Sukoharjo, 2015). During the study process an impression was found that the coverage of Iron tablets consumption by targeted group of young women was not attained. It was proven with 5 out of 8 young women stated that they did not comply to consume the given Iron Tablets supplement. Some conveyed reasons related to the low consumption of Iron Tablets are afraid of the side effect, avoiding nausea, and not fond of taking medicine.

"I do not take it, but I still keep the pills. Because I was told once by my friends that it will give us things, nausea, heavy period, so I'm afraid of taking it" (Anemic Young Women).

"One of my friends said that I should not take it during period since it will make the blood overflowing. I got frightened and then I stopped taking it since entering grade XI.” (Remaja Putri Anemia).

The commitment of educational sector in having independent outlet greatly influenced the sustainability of Gerakan Jumat Pintar policy. The commitment of the stakeholders was still low since there was no fund could be used in the implementation of the activity related to the policy of "Free of Charge School" 
"The obstacle is because the school fee is free, so there is no fund to be allocated on it. No development fee, no tuition, no fee for any activity" (Vice Principal)

"I haven't give it a try, lets see later I will make something with Youth Red Cross, lets have it socialized first. Whether they intend to do it or not. To buy it, related to the fund we should ask first about the readiness, since it is risky to take fund in such a way in Sukoharjo (School Health Unit officer).

\begin{tabular}{lll}
\hline \multicolumn{3}{c}{ Discussion } \\
\hline $\begin{array}{l}\text { 1. The preparation of } \\
\text { provider }\end{array}$
\end{tabular}

According to the study by Rogayah et al., (2015), the existence of written program organization in a form of Stipulation Letter or Working agreement between related parties may bind commitment, support and responsibility from the caretaker of the related program. Integration of all sectors needs involvement and commitment various level of related institution. However the advocacy on the implementation of Gerakan Jumat Pintar policy was only conducted verbally so that the partnership commitment was not strong.

The other drawback was that the implementation guidelines were delivered in spoken language only during socialization meeting and agreement on Gerakan Jumat Pintar in 2014. Meanwhile the operational guidance was very important to explain the role and responsibility between related health personnel and independent service provider that was school. As in a study made by Tondong et al., (2014) that lack of clarity on the role of each partner member in the partnership management and the absence of clear policy guidance may obstruct the implementation of partnership process so it leads to the failure of partnership to attain the purpose.
Based on the characteristics and number of human resources of Gerakan Jumat Pintar policy actors that already existed, it was considered sufficient. The availability of human resources is important in the implementation of activity management of certain policy, which definitely should be supported by other resources, in which in the study was Iron Tablets inventory (Suharno, 2013).

\section{IEC Strategy}

In general IEC strategy which was attemptted had been maximally in delivering information on purpose and benefits of Gerakan Jumat Pintar to be able to attract the attention of targeted young women by using various methods and current media. However the final result of material understanding which was followed up by the occurrence of awareness and compliance in consuming Iron Tablets back again depended on each individual of young women

\section{Target and Dosage of Iron Tablets Administration}

In the stage of determining the target number, it was determined by existing real data in working area of each Community Healthcare Center in accordance with what proposed by each related school. It was in accordance with the guidelines given by Kementerian Kesehatan RI (2015c), that one of the methods to calculate the target is by using real target data from Community Health Center that is recapitulation data on total anemic adolescents from sub-district level.

The process of Iron Tablets administration program service had been in accordance with the procedure in Health Ministry Regulation no. 88/2014 on Standard of Iron Tablets for Women of Reproductive Age and Pregnant Women. However there was discrepancy on the implementation of Iron Tablets in independent outlets since it was given only once a week. 


\section{Procurement and distribution of Iron Tablets}

The fund source of policy implementation mostly still came from governmental subsidy which also possessed budgeting constraint therefore it would not be able to meet the needs in the future. It is in accordance with the study by Rogayah et al., (2015) that states that fund dependency toward donor without nay exit strategy for other source of financing will give impact to the dormant of field activity.

However, if it coordinated students fund in a form of independent outlet would also get stuck with the policy of "Free of Charge School" in which the policy forbids to collect contribution from the students at school. Meanwhile the school also possessed constraints on the fund in which it only obtained operational fund from School Operational Aids (BOS) fund

Tablets distribution had met the existing procedure (Depkes RI, 2003). If school did not yet independently distribute Iron tablets, nutritionist from Community Health Center would take the items from regency pharmacy warehouse and afterward distributed it to each school based on the target needs.

Iron Tablets distribution in schools with independent outlet started by placing order by School Health Unit Officres to the pharmacy that supplied the medication, then the pharmacy would buy it for the school from pharmacy distributor. There was a weakness in the scheme since it was difficult to find pharmacy partner who wanted to provide the need for Iron Tablets related to pharmacy's fidelity not to sell Iron Blood carelessly.

\section{Observation and Monitoring}

It needs perception equality in recording and reporting system so that it will not incur ambiguity in observation and monitoring (Irawati, 2012). Observation and monitoring obtained from the study was not yet maximally implemented both in high range level and also low level.

Reporting was only conducted in informal/spoken from school to community healthcare center related to the coverage of Iron Tablets distribution without reporting the coverage of Iron tablets consumption by young women. Subsequently, community healthcare center reported in written form the result obtained from schools once in every year.

The implementation of policy observation and monitoring was beneficial to evaluate whether the activity worked well or not. It is in accordance with Dunn (2010) opinion in which evaluation or assessment is a stage that is closely related to monitoring activity since evaluate activity may use the data provided from monitoring activity.

\section{Attainment of Accomplishment}

The first accomplishment indicator was the reduction of anemia prevalence on young women. It had met the expectation by reducing to 28.08\% (Dinkes Sukoharjo, 2015). However the prevalence reduction meant by Health Office may not represent the real anemia prevalence on young women in Sukoharjo Regency.

The reason of the mistake in determining anemia prevalence on young women by Sukoharjo Health Office was the young women anemia incidence rate obtained from data during enlistment of anemic young women divided by total young women who were involved in the socialization as many as 1,200 young women, not by all young women in Sukoharjo Regency. Najmah (2015) states that to get prevalence rate it is calculated by dividing the number of people with certain disease with number of people who are at risk in the group.

Sample used in the blood check survey were only young women from 12 
schools, it was related to the limited that was received. Blood check was also conducted once a year without any evaluation on repeated blood check on the target of Iron Tablets administration. Therefore, the result had not yet covered the entire anemic young women in Sukoharjo Regency.

Compliance coverage in consuming iron tablets was also the determinant factor of Gerakan Jumat Pintar policy accomplishment. Five out of 8 subjects of the study admitted that they did not comply to consume iron tablets given, although they understood well the meaning of early anemia countermeasure. In accordance with the study result by Kautshar (2013) that adequate knowledge on anemia may not yet encourage pregnant women to comply more in consuming Fe tablets, however there is a tendency that most pregnant women who comply, have adequate knowledge. The statement is supported by Suryani et al., (2015) that good knowledge not necessarily may influence one's behavior in overcoming anemia.

The last indicator of accomplishment was the establishment of independent outlet. Out of 12 schools existed in Sukoharjo only 1 school that committed to follow up the Iron tablets administration independently through independent outlet. According to Tondong (2014) the commitment is needed to strengthen the policy implementation. Policy implementation process should have definite legal basis so that it ensures the compliance of field officers and the target group, also the support from stakeholders and commitment as well as expertise of policy executors so that the policy implementation can be successful. The main reason of the lack of commitment of the stakeholders in establishing their own independent outlet was the absence of activity fund source.
Based on the result of analysis that had been conducted it can be concluded that the implementation of Gerakan Jumat Pintar policy in reducing anemia on young women in Sukoharjo Regency did not work optimally yet. The absence of legal basis was the main reason of the low commitment of policy actors and target. It was marked by the low intention of school in establishing independent outlet, and the low awareness of young women in consuming Iron tablets regularly.

\begin{tabular}{c}
\hline REFERENCE \\
\hline Depkes RI (2003). Program Penanggulang- \\
an Anemia Gizi pada Wanita Usia \\
Subur (WUS). Jakarta: Depkes RI. \\
Dewi AB, Pujiastuti N, Fajar I (2013). Ilmu \\
Gizi untuk Praktisi Kesehatan. Yogya- \\
karta: Graha Ilmu.
\end{tabular}

Dinkes Sukoharjo (2015). Data Anemia dan KEK Remaja Putri Kab. Sukoharjo Tahun 2015. Sukoharjo: Dinas Kesehatan Kab. Sukoharjo.

(2016). Profil Kesehatan Kabupaten Sukoharjo Tahun 2015. Sukoharjo: Dinas Kesehatan Kab. Sukoharjo.

Irawati E (2012). Gambaran Keterpaduan Program KIA dan Gizi dalam Pelaksanaan Distribusi Tablet Fe Ibu hamil di Puskesmas Perawatan Pagatan Kabupaten Tanah Bumbu Propinsi Kalimantan Selatan. Skripsi. UI: Fakultas Kesehatan Masyarakat.

Kautshar N, Suriah, Jafar N (2013). Kepatuhan Ibu Hamil dalam Mengonsumsi Tablet zat Besi (Fe) di Puskesmas Bara-Baraya Tahun 2013. Diakses dari http://pasca.unhas.ac.id/jurnal/files/2838ec295ddbb8912d283bac2b79fa48.pdf Diakses 18 November 2016.

Dinas Kesehatan Kecamatan Sukoharjo (2014). Sosialisasi Penanggulangan Anemia Gizi pada Remaja Putri/WUS. 
Diakses dari http://www. Sukoharjo.sukoharjokab.go.id/sosialisasipenanggulangan-anemia-gizi-padaremaja-putri-wus.html pada 15 Mei 2016.

Kementerian Kesehatan RI (2014). Permenkes No. 88 Tahun 2014 tentang Standar Tablet Tambah Darah Bagi Wanita Usia Subur Dan Ibu Hamil. Jakarta: Kementerian Kesehatan RI. (2015a). Profil Kesehatan Indonesia 2014. Surveilans Gizi. Jakarta.

(2015b). Petunjuk Pelaksanaan Pemberian Tablet Tambah Darah.

Kementerian Kesehatan RI dan Millenium Challenge Account-Indonesia (2015c). Pedoman Program Untuk Ibu Hamil di Wilayah Program Kesehatan dan Gizi Berbasis Masyarakat. Jakarta.

Najmah (2015). Epidemiologi: untuk Mahasiswa Kesehatan Masyarakat. Jakarta: RajaGrafindo Persada.

Ngatu ER, Rochmawwati L (2015). Hubungan Pengetahuan tentang Anemia pada Remaja dengan Pemenuhan Kebutuhan Zat Besi pada Siswi SMKN 4 Yogyakarta. Jurnal Kebidanan Indonesia, 6(1): 16-26.
Rogayah H, Mahendradhata Y, Padmawati RS (2015). Evaluasi Program Terpadu Pengendalian Malaria, Pelayanan Ibu Hamil dan Imunisasi di Kabupaten Hulu Sungai Selatan dan Kota Banjarbaru Provinsi Kalimantan Selatan. Jurnal Kebijakan Kesehatan Indonesia, 4(1): 26-31.

Suharno (2013). Dasar-dasar Kebijakan Publik: Kajian Proses dan Analisis Kebijakan. Yogyakarta: UNY Press.

Suryani D, Hafiani R, Junita R (2015). Analisis Pola Makan dan Anemia Gizi Besi pada Remaja Putri Kota Bengkulu. JKMA, 10(1): 11-18.

Tondong MA, Mahendradhata Y, Ahmad RA (2014). Evaluasi Implementasi Public Private Mix Pengendalian Tuberkulosis di Kabupaten Ende Provinsi Nusa Tenggara Timur Tahun 2012. Jurnal Kebijakan Kesehatan Indonesia, 3(1): 37-42.

Wiknjosastro H (2007). Ilmu Kebidanan. Jakarta: Yayasan Bina Pustaka Sarwono Prawirohardjo. 